\title{
Complications in the treatment with alveolar extraosseous distractors. Literature review
}

\author{
Alfredo Rodriguez-Grandjean ${ }^{1}$, David Reininger ${ }^{2}$, Juan López-Quiles ${ }^{3}$ \\ ${ }^{1}$ DDS. Master in Oral Surgery and Implantology, Complutense University of Madrid \\ ${ }^{2}$ DDS. Master in Oral Surgery and Implantology, Complutense University of Madrid \\ ${ }^{3}$ DDS,MD,PhD. Maxillofacial Surgeon, Associate Professor, Department of Oral Surgery and Maxillofacial Surgery, Com- \\ plutense University of Madrid
}

Correspondence:

Department of Oral Surgery and Maxillofacial Surgery

Complutense University of Madrid, Spain

Plaza de Ramón y Cajal, 3

28040 Madrid, Spain

jlopezquiles@odon.ucm.es

Rodriguez-Grandjean A, Reininger D, López-Quiles J. Complications in the treatment with alveolar extraosseous distractors. Literature review. Med Oral Patol Oral Cir Bucal. 2015 Jul 1;20 (4):e518-24.

http://www.medicinaoral.com/medoralfree01/v20i4/medoralv20i4p518.pdf

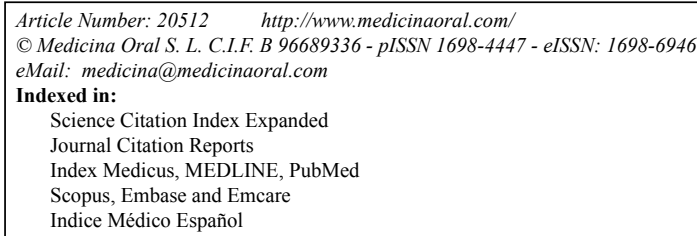

\begin{abstract}
Background: To review the literature that analyses the types and frequency of complications associated with the use of extraosseous alveolar distraction from 2007 to 2013.

Material and Methods: Review of the literature in PubMed, using these keywords; alveolar ridge, alveolar distraction osteogenesis, complication, literature review. Inclusion criteria were: articles published between 2007 and 2013 that included the distraction protocol, the complications encountered and the time when they occurred.

Results: According to the above criteria, 12 articles were included in this review, where 334 extraosseous distractors were placed and 395 complications were encountered, of which 19 (4.81\%) were intraoperative, 261 (66.07\%) postoperative and $115(29.11 \%)$ were postdistraction. The most common complication was the incorrect distraction vector found in 105 cases $(26.58 \%)$, in 23 cases (5.82\%) there were severe complications, of which 14 (3.54\%) were mandibular fracture and $9(2.27 \%)$ were fractures of the distractor elements.

Conclusions: According to this review, although alveolar distraction is a safe and predictable technique, it can cause complications; however, they are usually minor and easily resolved without affecting the treatment outcome.
\end{abstract}

Key words: Alveolar ridge, alveolar distraction osteogenesis, complication, literature review.

\section{Introduction}

In many situations different anatomical limitations (1) can make implant placement difficult or even impossible. In the case of the upper jaw, some of these limitations are: centripetal resorption of the alveolar process, maxillary sinus pneumatisation, and the presence of the nasal cavity and nasopalatine duct together with bone quality type 3 or 4 , in the Lekholm and Zarb classification. For the mandible, the main problem is usually the mandibular canal (2), as well as a decrease in the 
symphyseal angle which may cause problems in terms of the inclination of the implants. In other situations, despite having enough bone to place the fixture, high bone resorption could lead to an implant placement with an inadequate crown-to-implant ratio so, in addition to compromising the aesthetic outcome, substantial adverse biomechanical forces for these implants would be caused. Currently, there are various techniques to solve these types of defects, such as (3-7): onlay bone grafts, inlay bone grafts, guided bone regeneration and alveolar distraction osteogenesis (DO).

Alveolar DO is defined as the creation of new bone along with adjacent soft tissue after controlled and gradual bone displacement of the bone fragment obtained by surgical osteotomy. This process generates forces that maintain and stimulate regeneration and growth, which is known as the Law of Tension Stress $(8,9)$.

The ability of alveolar DO to regenerate bone and soft tissues makes it an interesting alternative to conventional methods of bone regeneration as it achieves adequate vertical bone augmentation with accompanying soft tissue, optimal aesthetic and functional results, as well as a correct crown-to-implant ratio.

In addition to bone and soft tissue regeneration, the main advantages of alveolar DO are: low infection rate, low resorption, and reduced implant placement time (10). Among the disadvantages, the presence of a high rate of complications are mentioned; however, most of them are simple: difficulty in completing the osteotomy on the lingual side, intraoperative bleeding, paresthesia, hematoma, soft tissue dehiscence, exposure of distractor elements, exposure of the mobilized bone, pain during rod activation, ulcers caused by distractor elements, insufficient attached gingiva (10-26). Severe complications are rare (11-14), with those being: mandibular fracture and fracture of the distractor elements (11,15-20). Several authors mentioned incorrect distraction vector as the most frequent complication (11-14,16-23).

Since the last comprehensive literature review of the complications of alveolar DO by Saulacic et al. (15) covered from January 1996 to July 2008, and it did not include all the articles published in 2007 and 2008, the aim of this review is to analyse the types and frequency of complications associated with the use of extraosseous alveolar distraction between 2007 and 2013.

\section{Material and Methods}

The literature review was conducted in PubMed, from January 2007 to December 2013, using the following key words; alveolar ridge, alveolar distraction osteogenesis, complication, literature review.

The selection criteria were: articles which included the number of extraosseous distractors placed per patient, distractor location, distraction protocol, complications, and average total gain. Moreover, articles had to include the time when the complication occurred, which may have been either intraoperative or postoperative, during distraction and/or consolidation periods, and postdistraction complications. The following exclusion criteria were considered: studies where intraosseous distractors were used, studies in animals, in patients with any type of bone disease, in patients with a history of facial radiation or treated with intravenous or oral bisphosphonates for more than 3 years.

The side effects caused by the surgery such as pain, haematoma or mucosa inflammation were also included as complications of distraction.

\section{Results}

The initial search resulted in 53 articles, but only 12 of them met the inclusion criteria. In one of these studies (11) both intraosseous and extraosseous distractors were used and complications were not classified according to the type of device. Nevertheless, they were classified according to the time they occurred, so the decision was made to include this article in the review. In these 12 articles, 334 extraosseous distractors were placed, 251 $(75.15 \%)$ in the mandible and $81(24.25 \%)$ in the maxilla (Table 1).

As for the distraction protocol, three parameters were analysed: the latency period, distraction rate and consolidation period. The latency period lasted $5-8.1$ days, with an average of 6.67 days. The distraction rate was $0.5-1 \mathrm{~mm} /$ day, $0.85 \mathrm{~mm} /$ day on average. The consolidation period lasted 4-18 weeks with an average of 11.83 weeks (Table 1). In total, 652 implants were placed (Table 2).

A total number of 395 complications were found, of which $19(4.81 \% \mathrm{~T}$, where $\mathrm{T}$ is total number of complications in all stages) were intraoperative, $261(66.07 \% \mathrm{~T})$ postoperative and $115(29.11 \% \mathrm{~T})$ postdistraction (Fig. 1).

Of the total cases of intraoperative complications, 8 (42.1\%) were due to the difficulty in completing the osteotomy on the lingual side, in 4 cases $(21.05 \%)$ there was a fracture of the bone to be distracted, in 3 cases $(15.78 \%)$ a mandibular fracture occurred, in another 3 cases $(15.78 \%)$ the problem was the rod interfering with the occlusion and finally, in 1 case $(5.26 \%)$ there was bleeding (Table 2).

Of the total number of postoperative complications, 105 cases $(40.22 \%)$ were due to incorrect distraction vector; in 41 cases (15.71\%) paresthesia, 19 (7.27\%) mucosal dehiscence, $16(6.13 \%)$ pain, $14(5.36 \%)$ mandibular fracture, $11(4.21 \%)$ infection, $11(4.21 \%)$ due to exposure of distracted bone, $9(3.44 \%)$ fracture of the distractor elements, 6 (2.3\%) mucosal inflammation, 6 (2.3\%) rod interference with occlusion, 5 (1.9\%) distractor failure, $4(1.53 \%)$ ulcers, $3(1.15 \%)$ hematoma, $3(1.15 \%)$ mucosal hyperplasia, $3(1.15 \%)$ inappropriate activation of the distractor, $2(0.76 \%)$ epithelial invagination, $1(0.38 \%)$ adjacent tooth mobility, $1(0.38 \%)$ lack of attached gin- 
Table 1. Number of distractors and distraction protocol.

\begin{tabular}{|c|c|c|c|c|}
\hline Articles & $\begin{array}{l}\text { Number of } \\
\text { distraction }\end{array}$ & Anatomic region & Type of device & Distraction protocol \\
\hline Perdijk et al. 2007 (18) & 45 & Mandible (45) & Extraosseous & $\begin{array}{l}\text { Latency period: } 7 \text { days } \\
\text { Distraction rate: } 0.5 \mathrm{~mm} / \text { day } \\
\text { Consolidation period: } 12 \text { weeks }\end{array}$ \\
\hline Wolvius et al. 2007 (13) & 20 & $\begin{array}{l}\text { Anterior maxilla (10) } \\
\text { Posterior maxilla (2) } \\
\text { Anterior mandible (4) } \\
\text { Posterior mandible (4) }\end{array}$ & Extraosseous & $\begin{array}{l}\text { Latency period: } 7 \text { days } \\
\text { Distraction rate: } 0.9 \mathrm{~mm} / \text { day } \\
\text { Consolidation period: } 8-16 \text { weeks }\end{array}$ \\
\hline Mazzonetto et al. 2007 (14) & 55 & $\begin{array}{l}\text { Anterior maxilla (22) } \\
\text { Posterior maxilla (2) } \\
\text { Anterior mandible (3) } \\
\text { Posterior mandible (28) }\end{array}$ & Extraosseous & $\begin{array}{l}\text { Latency period: } 7 \text { days } \\
\text { Distraction rate: } 1 \mathrm{~mm} / \text { day } \\
\text { Consolidation period: } 12 \text { weeks }\end{array}$ \\
\hline Marchetti et al. 2007 (16) & 10 & $\begin{array}{l}\text { Maxilla (2) } \\
\text { Mandible (8) }\end{array}$ & Extraosseous & $\begin{array}{l}\text { Latency period: } 7 \text { days } \\
\text { Distraction rate: } 0.5 \mathrm{~mm} / \text { day } \\
\text { Consolidation period: } 10-18 \\
\text { weeks }\end{array}$ \\
\hline Saulacic et al. 2007 (11) & 29 & $\begin{array}{l}\text { Anterior maxilla (2) } \\
\text { Anterior mandible (2) } \\
\text { Posterior mandible (25) }\end{array}$ & Extraosseous & $\begin{array}{l}\text { Latency period: } 7 \text { days } \\
\text { Distraction rate: } 1 \mathrm{~mm} / \text { day } \\
\text { Consolidation period: } 12 \text { weeks }\end{array}$ \\
\hline Uckan et al. 2007 (25) & 10 & $\begin{array}{l}\text { Anterior maxilla (4) } \\
\text { Posterior maxilla (2) } \\
\text { Anterior mandible (2) } \\
\text { Posterior mandible (2) }\end{array}$ & Extraosseous & $\begin{array}{l}\text { Latency period: } 5 \text { days } \\
\text { Distraction rate: } 1 \mathrm{~mm} / \text { day } \\
\text { Consolidation period: } 8-12 \text { weeks }\end{array}$ \\
\hline Bianchi et al. 2008 (8) & 5 & Posterior madible (5) & Extraosseous & $\begin{array}{l}\text { Latency period: } 5-7 \text { days } \\
\text { Distraction rate: } 0.5-1 \mathrm{~mm} / \text { day } \\
\text { Consolidation period: } 12-16 \\
\text { weeks }\end{array}$ \\
\hline Uckan et al. 2008 (26) & 24 & $\begin{array}{l}\text { Anterior maxilla (9) } \\
\text { Posterior maxilla (4) } \\
\text { Anterior mandible (8) } \\
\text { Posterior mandible (3) }\end{array}$ & Extraosseous & $\begin{array}{l}\text { Latency period: } 5 \text { days } \\
\text { Distraction rate: } 0.8-1 \mathrm{~mm} / \text { day } \\
\text { Consolidation period: } 8-12 \text { weeks }\end{array}$ \\
\hline Gunbay et al. 2008 (12) & 2 & Posterior mandible (2) & Extraosseous & $\begin{array}{l}\text { Latency period: } 7 \text { days } \\
\text { Distraction rate: } 0.8 \mathrm{~mm} / \text { day } \\
\text { Consolidation period: } 6-8 \text { weeks }\end{array}$ \\
\hline Ettl et al. 2010 (19) & 36 & $\begin{array}{l}\text { Maxilla (11) } \\
\text { Mandible (25) }\end{array}$ & Extraosseous & $\begin{array}{l}\text { Latency period: } 8.1 \text { days } \\
\text { Distraction rate: } 0.9 \mathrm{~mm} / \text { day } \\
\text { Consolidation period: } 18 \text { weeks }\end{array}$ \\
\hline Zwetyenga et al. 2012 (20) & 54 & $\begin{array}{l}\text { Anterior mandible (11) } \\
\text { Posterior mandible (43) }\end{array}$ & Extraosseous & $\begin{array}{l}\text { Latency period: } 7 \text { days } \\
\text { Distraction rate: } 1 \mathrm{~mm} / \text { day } \\
\text { Consolidation period: } 12 \text { weeks }\end{array}$ \\
\hline Ugurlu et al. 2012 (23) & 44 & $\begin{array}{l}\text { Anterior maxilla (8) } \\
\text { Posterior maxilla (5) } \\
\text { Anterior mandible (24) } \\
\text { Posterior mandible (7) }\end{array}$ & Extraosseous & $\begin{array}{l}\text { Latency period: } 7 \text { days } \\
\text { Distraction rate: } 1 \mathrm{~mm} / \text { day } \\
\text { Consolidation period: } 4-14 \text { weeks }\end{array}$ \\
\hline
\end{tabular}

giva and $1(0.38 \%)$ because of soft tissue fibrosis related to the rod (Table 2).

Of all postdistraction complications, the most common one was the need for grafting in 27 cases $(23.47 \%)$ followed by $23(20 \%)$ cases of implant dehiscence. In 19 cases $(16.52 \%)$ the problem was the failure in implant osseointegration, 19 (16.52\%) were due to implant fenestration, $13(11.3 \%)$ lack of attached gingiva, 11 $(9.56 \%)$ lack of height, so the Tinti technique was used and finally, in 3 cases $(2.60 \%)$ implants presented periimplantitis (Table 2).

The incorrect distraction vector was the most common complication, observed in 105 cases, accounting for $26.58 \%$ of all complications, and $40.22 \%$ of postoperative complications. Severe complications were found in 24 cases $(6.07 \% \mathrm{~T})$, of which $15(3.79 \% \mathrm{~T})$ corresponded to mandibular fracture and $9(2.27 \% \mathrm{~T})$ corresponded to fracture of distractor elements.

\section{Discussion}

In recent years, distraction osteogenesis has been established as an effective and predictable method for alveolar bone augmentation, which improves the relationship between the patient's alveolar ridges. This 
Table 2. Complications according to time of occurrence.

\begin{tabular}{|c|c|c|c|c|}
\hline Articles & $\begin{array}{l}\text { intraoperative } \\
\text { complication }\end{array}$ & $\begin{array}{c}\text { Postoperative complication, during distracción and } \\
\text { consolidation }\end{array}$ & Postdistraction complication & $\begin{array}{c}\text { No. Of } \\
\text { implants }\end{array}$ \\
\hline Perdijk 2007 (18) & - Mandibular fracture (1) & $\begin{array}{l}\text { - Hematoma in the floor of the mouth or in the chin region (2) } \\
\text { - Infection (3) } \\
\text { - Perforation of the mucosa (4) } \\
\text { - Incorrect vector of distraction (45) } \\
\text { - Mandibular farcture (8) } \\
\text { - Paresthesia (13) }\end{array}$ & - Lost implants (9) & 99 \\
\hline $\begin{array}{l}\text { Wolvius et al. } \\
2007 \text { (13) }\end{array}$ & - Mandibular fracture (1) & - Incorrect vector of distraction (10) & $\begin{array}{l}\text { - Lost implants (1) } \\
\text { - Poor bone formation ( } 10 \text { height; } 5 \text { width) }\end{array}$ & 63 \\
\hline $\begin{array}{l}\text { Mazzonetto et al. } \\
2007 \text { (14) }\end{array}$ & $\begin{array}{l}\text { - Difficulty incompleting } \\
\text { the osteotomy on the } \\
\text { lingual side (1) }\end{array}$ & $\begin{array}{l}\text { - Paresthesia (6) } \\
\text { - Infection (8) } \\
\text { - Hyperplasia (3) } \\
\text { - Fracture of screw (1) } \\
\text { - Lack of device activation (3) } \\
\text { - Incorrect vector of distraction (3) } \\
\text { - Epithelium invagination (1) } \\
\text { - Fracture of device (1) } \\
\text { - Failure of device (1) } \\
\text { - Dehiscence (3) }\end{array}$ & $\begin{array}{l}\text { - Inadequate height (1) } \\
\text { - Inadecuate width (21) }\end{array}$ & \\
\hline $\begin{array}{l}\text { Marchetti } \text { et al. } \\
2007 \text { (16) }\end{array}$ & & $\begin{array}{l}\text { - Pain (10) } \\
\text { - Incorrect vector of distraction (1) } \\
\text { - Insufficient attached gingiva (1) }\end{array}$ & $\begin{array}{l}\text { - Lost implant (1) } \\
\text { - Inadecuate width (1) }\end{array}$ & 36 \\
\hline $\begin{array}{l}\text { Saulacic et al. } \\
2007 \text { (11) }\end{array}$ & $\begin{array}{l}\text { - Difficulty incompleting } \\
\text { the osteotomy (1) } \\
\text { - Fracture of transport } \\
\text { segment (3) } \\
\text { - Interference of } \\
\text { distraction rod with } \\
\text { oclussion (3) }\end{array}$ & $\begin{array}{l}\text { - Hematoma (1) } \\
\text { - Paresthesia (6) } \\
\text { - Pain (4) } \\
\text { - Dehiscence (4) } \\
\text { - Exposure of transport bone (8) } \\
\text { - Ulcers resulted from the component of distractor (4) } \\
\text { - Incorrect vector of distraction (5) }\end{array}$ & $\begin{array}{l}\text { - Dehiscence (23) } \\
\text { - Fenestration (19) }\end{array}$ & 78 \\
\hline $\begin{array}{l}\text { Uckan et al. } 2007 \\
\text { (25) }\end{array}$ & & $\begin{array}{l}\text { - Oclussal interference (3) } \\
\text { - Incorrect vector of distraction (2) }\end{array}$ & & 17 \\
\hline $\begin{array}{l}\text { Bianchi } \text { et al. } \\
2008(8)\end{array}$ & & $\begin{array}{l}\text { - Incorrect vector of distraction (2) } \\
\text { - Mandibular fracture (3) } \\
\text { - Fracture of device (1) } \\
\text { - Failure of device (3) }\end{array}$ & $\begin{array}{l}\text { - Peri-implant bone resorption greated } \\
\text { than } 1.5 \mathrm{~mm} \text { in the first year after } \\
\text { prosthetic loading (1) }\end{array}$ & 16 \\
\hline $\begin{array}{l}\text { Uckan et al. } 2008 \\
\text { (26) }\end{array}$ & - Bleeding (1) & $\begin{array}{l}\text { - Interference of distraction rod with oclussion (3) } \\
\text { - Incorrect vector of distraction (7) } \\
\text { - Movility of the adjacent teeth(1) } \\
\text { - Exposure of transport bone (1) } \\
\text { - Paresthesia (1) } \\
\text { - Fracture of device (1) }\end{array}$ & - Lost implants (4) & 46 \\
\hline $\begin{array}{l}\text { Gunbay } \text { et al. } \\
2008 \text { (12) }\end{array}$ & & $\begin{array}{l}\text { - Pain (1) } \\
\text { - Incorrect vector of distraction (1) } \\
\text { - Paresthesia (4) } \\
\text { - Fracture of screw (1) } \\
\text { - Dehiscence (1) }\end{array}$ & & 14 \\
\hline $\begin{array}{l}\text { Ettl } \text { et al. } 2010 \\
\text { (19) }\end{array}$ & & $\begin{array}{l}\text { - Incorrect vector of distraction (15) } \\
\text { - Fracture of device element (2) } \\
\text { - Dehiscence (2) } \\
\text { - Mandibular fracture (1) }\end{array}$ & $\begin{array}{l}\text { - Insufficient attached gingiva (13) } \\
\text { - Lost implants (4) }\end{array}$ & 82 \\
\hline $\begin{array}{l}\text { Zwetyenga } \text { et al. } \\
2012(20)\end{array}$ & & $\begin{array}{l}\text { - Incorrect vector of distraction (8) } \\
\text { - Mandibular fracture (2) } \\
\text { - Paresthesia (9) } \\
\text { - Mucosa inflammation (6) } \\
\text { - Exposure device element (4) } \\
\text { - Exposure bone (2) }\end{array}$ & & 127 \\
\hline $\begin{array}{l}\text { Ugurlu } \text { et al. } \\
2012(23)\end{array}$ & - Mandibular fracture (2) & $\begin{array}{l}\text { - Paresthesia (2) } \\
\text { - Dehiscence (1) } \\
\text { - Pain (1) } \\
\text { - Incorrect vector of distraction (6) } \\
\text { - Fracture of device element (1) } \\
\text { - Fracture of device (1) } \\
\text { - Failure of device (1) } \\
\text { - Fibrotic soft-tissue formation(1) } \\
\text { - Epithelium invagination (1) }\end{array}$ & - Peri-implant bone resorption (2) & 74 \\
\hline
\end{tabular}

technique allows a vertical bone augmentation of more than $12 \mathrm{~mm}$, without the need for grafts (22). The main disadvantage is the large number of complications.

Despite being one of the most used techniques in recent years to solve the problem of alveolar defects, certain authors, such as Enislidis et al. (17) and Perdijk et al. (18), regard DO as a dangerous technique that does not provide advantages over conventional techniques used to increase atrophic alveolar ridges.

If we compare alveolar DO with autogenous grafts to solve vertical bone defects, resorption with autogenous grafts ranges from $25 \%$ to $42 \%(6,27)$ and the vertical gain is about $5 \mathrm{~mm}(6,8)$, while with alveolar DO vertical bone gain can exceed $12 \mathrm{~mm}(8,11,26)$, with varying degrees of resorption. All authors agree that resorption occurs at the end of the period of consolidation. McAllister et al. (28) stated that resorption is not significant, Ettl et al. (19) described a resorption of $1.8 \mathrm{~mm}$, Chiapasco et al. (22) mentioned a degree of resorption of $0.3 \mathrm{~mm}$, Polo et al. (29) $0.9 \mathrm{~mm}$, Jensen et al. (30) and Saulacic et al. (31) $1.6 \mathrm{~mm}$.

Despite the many advantages of the alveolar DO al- 


\section{Distraction Complications}

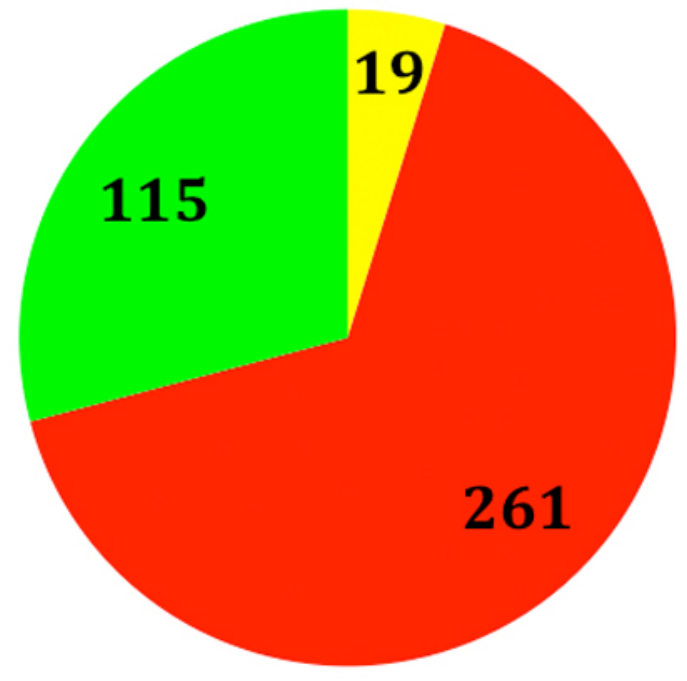

Fig. 1. Distraction Complications.

\section{Intraoperative}

- Postoperative

- Postdistraction ready described, such as the ability to regenerate bone and soft tissue, present low infection rate, low resorption and reduce the time in the placement of the implant (10), this technique causes many complications . These range from wound dehiscence to mandibular fracture. In this review, it has been observed that the number of complications increases with the number of cases. The distraction vector is the most common complication, with the following prevalence: 5.45\% (14), 10\% (16), 13.63\% (23), 14.8\% (20), 17.2\% (11), 29.1\% (26), 40\% (8), $41.6 \%(19), 50 \%(12,13,25)$ and $100 \%(18)$. The tension generated by the lingual / palatal mucosa or by the muscles of the floor of the mouth generates an incorrect inclination of the distraction vector as the fractured fragment is raised (19). This is a very common complication $(17,22)$ that can be solved by the orthodontic replacement (32) of the osteotomized fragment. If the fragment has healed, it is necessary to resort to a new osteotomy and the piece must be placed in the correct position $(33,34)$. To prevent vector displacement, a temporary prosthesis (28) can be used or orthodontic techniques with microimplants (35) during distraction can be performed; alternatively, the bottom of the distractor root can be fixed to the basal bone.

Of all the possible complications that may arise during and after alveolar distraction osteogenesis, mandibular fracture $(28,30,36)$ is the most severe; however, despite being the most severe complication, it does not neces- sarily imply treatment failure, which surprises us. Many authors suggest that the alveolar DO should be avoided in the cases where mandibular height, measured preoperatively in a panoramic radiograph, is less than $10 \mathrm{~mm}$ $(18,30)$ because the risk of fracture is greatly increased. In this review, we have found that Perdjik et al. (18) mentioned a total of 9 cases of mandibular fractures, one intraoperative and 8 in the consolidation period, where the residual bone height is less than $10 \mathrm{~mm}$, Zwetyenga et al. (20) presented 2 cases, Ettl et al. (19) 1 case and Bianchi et al. (8) 3 cases, with a total of 15 mandibular fractures $(3.79 \% \mathrm{~T})$. Mandibular fracture was not mentioned in any of the other articles reviewed.

Moreover, fracture of a movable bone fragment was observed during the operation in 4 cases $(1.01 \% \mathrm{~T})$. If the fragment is small, it has to be removed, but if it is big it would have to be fixed with a miniplate. The fracture of a movable bone fragment may generate high residual bone resorption (11).

The fracture of distractor elements or device failure has also been described in this review $(8,12,14,19,23,26)$ and it may determine the success of treatment. In this situation, the procedure should be interrupted and the distractor must be removed as soon as possible.

One case $(25,26)(0.25 \% \mathrm{~T})$ of bleeding in the floor of the mouth during the osteotomy was described; this can be avoided with the use of ultrasound since it reduces the risk of blood vessel injury. However, despite avoid- 
ing injury of soft structures and facilitating osteotomy, some authors advocate the use of ultrasound instead of mechanical osteotomy (saws and chisels), which may increase the chance of postoperative and postdistraction complications (37).

Paresthesias occurred in 41 cases with a prevalence of $10.38 \% \mathrm{~T}$, lower than previous data obtained in the literature $(14,15)$, in all cases they were considered minor complications (14) since they were temporary and resolved with conservative treatment.

As for soft tissue complications, dehiscence occurred in 19 cases $(4.8 \%), 11$ patients $(2.78 \%)$ with exposure of movable bone, 6 cases $(1.51 \%)$ with inflammation of mucosa, 4 patients $(1.01 \%)$ with ulcers caused by the distractor, 2 patients $(0.5 \%)$ with epithelial invagination, and 1 case $(0.25 \%)$ of soft tissue fibrosis. There were also 28 cases $(7.09 \%)$ with lack of attached gingiva, which tend to be more frequent in alveolar DO cases that use extraosseous devices $(14,19)$, since the need to cover the device generates great strain on the mucosa and periosteum (18). These complications do not determine the outcome of treatment and can be resolved with conservative procedures, except for the lack of attached gingiva which may require connective grafts (30).

In this review, we noted that the incidence of hematoma and infection were not more relevant than in any other surgery and both are controlled with conservative treatment (11).

Normally, the activation of the distractor rod does not produce discomfort or pain, although in this review, 16 patients $(4.05 \%)$ reported pain during activation. This can be overcome by reducing the range of distraction from $1 \mathrm{~mm}$ to $0.5 \mathrm{~mm}$, which makes discomfort disappear in all cases. However, the average daily range is maintained by increasing the frequency of the adjustments. When performing the osteotomy, it is important to take into account that parallel or converging walls can cause discomfort during distraction and compromise the final result by blocking the mobile fragment, so osteotomies of the side walls should be divergent as recommended by Chiapasco et al. (22).

It is possible that the increase in bone increases the risk of dehiscence or fenestration in the vestibular face when placing the implants, and it may occasionally be necessary to use grafts. This is the most frequent postdistraction complication, as we have seen in this review, where it was necessary to use grafts in 27 cases $(6.83 \% \mathrm{~T})$. Similarly, we have observed that most of the postdistraction complications are related to implant placement. Of the 652 implants, 19 were lost in the early stages of the osseointegration, which gives us a success rate of $97.09 \%$, which is a similar implant success rate compared to natural bone $(19,38)$. In 23 cases $(5.82 \% \mathrm{~T})$ dehiscence occurred, 19 cases $(4.81 \% \mathrm{~T})$ presented fen- estration and in 11 cases $(2.78 \% \mathrm{~T})$ there was a lack of height. Multiple studies have demonstrated the occurrence of bone defects at the time of implant placement $(11,17,20)$. One of the causes described was related to the excessive length of the distractor root, as it transmits instability to the mobilized fragment and prevents the formation of new bone at the fracture site. To avoid bone defect problems, callus massages were performed since this technique is included in the distraction protocol because of the good results obtained (39).

Moreover, the narrow alveolar ridge before starting the distraction treatment favours the appearance of fenestrations or dehiscences when implants are placed. However, when the alveolar ridge conditions are unfavourable before starting distraction, bone defects should not be considered as distraction complications, and therefore should not be included in the different studies. Sometimes, when the alveolar ridge is unfavourable, multi-stage surgery is used by combining bone grafts and distraction (30).

It has been shown that the bone is maintained equally well in implants placed in postdistraction bone and those placed in native bone (19).

Mofid et al. (40) in a review of 3,278 alveolar DO cases, noted a marked learning curve, with lower rate of complications as the experience of the surgeons increased. Since alveolar DO is a new technique, many complications may be due to lack of experience, inadequate osteotomy, mandibular fracture, inadequate planning, poor device selection and a lack of experience in the surgical management of the distractor placement.

\section{Conclusions}

After analysing the nature of the complications in this review, we consider alveolar distraction osteogenesis as a technique of choice in correcting vertical bone defects because, despite causing multiple complications both during and after surgery, these complications do not usually affect the final outcome of treatment and can be easily resolved. Proper planning, protocols and handling will greatly reduce complications.

\section{References}

1. Sorní M, Guarinós J, García O, Peñarrocha M. Implant rehabilitation of the atrophic upper jaw: a review of the literature since 1999. Med Oral Patol Oral Cir Bucal. 2005;10 Suppl 1:E45-56.

2. Liu T, Xia B, Gu Z. Inferior alveolar canal course: a radiographic study. Clin Oral Implants Res. 2009;20:1212-8.

3. Vermeeren JI, Wismeijer D, van Waas MA. One-step reconstruction of the severely resorbed mandible with onlay bone grafts and endosteal implants. A 5-year follow-up. Int J Oral Maxillofac Surg. 1996;25:112-5.

4. Verhoeven JW, Ruijter J, Cune MS, Terlou M, Zoon M. Onlay gra$\mathrm{fts}$ in combination with endosseous implants in severe mandibular atrophy: one year results of a prospective, quantitative radiological study. Clin Oral Implants Res. 2000;11:583-94. 
5. Van Steenberghe D, Naert I, Bossuyt M, De Mars G, Calberson L, Ghyselen J, et al. The rehabilitation of the severly reabsorbed maxilla by simultaneous placement of autogenous bone grafts and implants: a 10 years evaluation. Clin Oral Investig. 1997;1:102-8.

6. Bianchi A, Felice P, Lizio G, Marchetti C. Alveolar distraction osteogenesis versus inlay bone grafting in posterior mandibular atrophy: a prospective study. Oral Surg Oral Med Oral Pathol Oral Radiol Endod. 2008;105:282-92.

7. Simion M, Jovanovic SA, Tinti C, Benfenati SP. Long-term evaluation of osseointegrated implants inserted at the time or after vertical ridge augmentation. A retrospective study on 123 implants with 1-5 year follow-up. Clin Oral Implants Res. 2001;12:35-45.

8. Ilizarov GA. The tension-stress effect on the genesis and growth of tissues. Part I. The influence of stability of fixation and soft-tissue preservation. Clin Orthop Relat Res. 1989;238:249-81.

9. Ilizarov GA. The tension-stress effect on the genesis and growth of tissues: Part II. The influence of the rate and frequency of distraction. Clin Orthop Relat Res. 1989;239:263-85.

10. Cano J, Campo J, Moreno LA, Bascones A. Osteogenic alveolar distraction: a review of the literature. Oral Surg Oral Med Oral Pathol Oral Radiol Endod. 2006;101;11-28.

11. Saulacic N, Somosa M, Leon MA, García A. Complications in Alveolar Distraction Osteogenesis: A Clinical Investigation. J Oral Maxillofac Surg. 2007;65:267-74.

12. Günbay T, Koyuncu BO, Akay C, Sipahi A, Tekin U. Results and complications of alveolar distraction osteogenesis to enhance vertical bone height. Oral Surg Oral med Oral Pathol Oral Radiol Endod. 2008;105:e7-e13.

13. Wolvius EB, Scholtemeijer M, Weijland WCJ, Hop KGH. Complications and relapse in alveolar distraction osteogenesis in partially dentulous patients. Int J Oral Maxillofac Surg. 2007;36:700-5.

14. Mazzonetto R, Allais M, Maurette PE, Moreira WF. A retrospective study of the potential complications during alveolar distraction osteogenesis in 55 patients. Int J Oral Maxillofac Surg. 2007;36:610.

15. Saulacic N, Zix J, Lizuka T. Complication rates and associated factors in alveolar distraction osteogenesis: a comprehensive review. Int J Oral Maxillofac Surg. 2009;38:210-7.

16. Marchetti C, Corinaldesi G, Pieri F, Degidi M, Piatelli A. Alveolar distraction ostegenesis for bone augmentation of severly atropic ridges in 10 consecutive cases: a histologic and histophometric study. J Periodontol. 2009;78:360-6.

17. Enislidis G, Fock N, Millesi-Schobel G, Klug C, Wittwer G, Yerit K, et al. Analysis of complications following alveolar distraction osteogenesis and implant placement in the partially edentulous mandibles. Oral Surg Oral Med Oral Pathol Oral Radiol Endod. 2005;100:25-30.

18. Perdijk FB, Meijer GJ, Strijen PJ, Koole R. Complications in alveolar distraction osteogenesis of the atrophic mandible. Int J Ora Maxillofac Surg. 2007;36:916-21.

19. Ettl T, Gerlach T, Schüsselbauer T, Gosau M, Reichert T, Driemel O. Bone resorption and complications in alveolar distraction osteogenesis. Clin Oral Invest. 2010;14:481-9.

20. Zwetyenga N, Vidal N, Ella B, Siberchicot F, Emparanza A. Results of oral implant-supported prostheses after mandibular vertical alveolar ridge distraction: a propos of 54 sites. Oral Surg Oral Med Oral Pathol Oral Radiol Endod. 2012;114:725-32.

21. Türker N, Basa S, Vural G. Evaluation of osseous regeneration in alveolar distraction osteogenesis with histological and radiological aspects. J Oral Maxillofac Surg. 2007;65:608-14.

22. Chiapasco M, Consolo U, Bianchi A, Ronchi P. Alveolar distraction osteogenesis for the correction of vertically deficient edentulous ridges: a multicenter prospective study on humans. Int J Oral Maxillofac Implants. 2004;19:399-407.

23. Ugurlu F, Cem Sener B, Dergin G, Garip H. Potential complications and precautions in vertical alveolar distraction osteogenesis: a retrospective study of 40 patients. J Craniomaxillofac Surg. 2013;41:569-73.
24. Gaggl A, Schultes G, Karcher H. Vertical alveolar ridge distraction with prosthetic treatable distractors: A clinical investigation. Int J Oral Maxillofac Implants. 2000;15:701-10.

25. Uckan S, Oguz Y, Bayram B. Comparison of intraosseous and extraosseous alveolar distraction osteogenesis. J Oral Maxillofac Surg. 2007;65:671-4

26. Uckan S, Veziroglu F, Dayangac E. Alveolar distraction osteogenesis versus autogenous onlay bone grafting for alveolar ridge augmentation: technique, complications and implants survival rates. Oral Surg Oral Med Oral Pathol Oral Radiol Endod. 2008;106:511-5. 27. Cordaro L, Amadé DS, Cordaro M. Clinical result of alveolar ridge augmentation with mandibular block grafts in partially edentulous patients prior to implant placement. Clin Oral Implants Res. 2002;13:103-11.

28. McAllister BS. Histologic and radiographic evidence of vertical ridge augmentation utilizing distraction osteogenesis: 10 consecutively placed distractors. J Periodontol. 2001;72:1767-79.

29. Polo WC, Cury PR, Sendyk WR, Gromatzky A. Posterior mandibular alveolar distraction osteogenesis utilizing an extraosseous distractor: a prospective study. J Periodontol. 2005;76:1463-8.

30. Jensen OT, Cockrell R, Kuhike L, Reed C. Anterior maxillary alveolar distraction osteogenesis: a prospective 5 -year clinical study. Int J Oral Maxillofac Implants. 2002;17:52-68.

31. Saulacic N, Somoza-Martin M, Gándara-Vila P, Garcia-Garcia A. Relapse in alveolar distraction osteogenesis: an indication for overcorrection. J Oral Maxillofac Surg. 2005;63:978-81.

32. Oh HK, Park HJ, Cho JY, Park YJ, Kook MS. Vector control of malpositioned segment during alveolar distraction osteogenesis by using rubber traction. J Oral Maxillofac Surg. 2009;67:608-12.

33. Mehra P, Figueroa R. Vector control in alveolar distraction osteogenesis. J Oral Maxillofac Surg. 2008;66:776-9.

34. Herford AS, Audia F. Maintaining vector control during alveolar distraction osteogenesis: a technical note. Int J Oral Maxillofac Implants. 2004;19:758-62.

35. Aizenbud D, Hazan-Molina H, Cohen M, Rachmiel A. 3D vector control during alveolar ridge augmentation using distraction osteogenesis and temporary anchoragedevices: a new technique. Int J Oral Maxillofac. Surg. 2012;41:168-70

36. Kim UK, Chung IK, Lee KH, Swift JQ, Seong WJ, Ko CC. Bone regeneration in mandibular distraction osteogenesis combined with compression stimulation. J Oral Maxillofac Surg. 2006;64:14981505 .

37.González-García A, Diniz-Freitas M, Somoza-Martín M, GarcíaGarcía A. Piezoeléctric and conventional osteotomy in alveolar distraction osteogenesis in a series of 17 patients. Int J Oral Maxillofac Implants. 2008;23:891-6.

38. Polo WC, de Araujo NS, Lima YB, Joly JC, Sendyk WR, Cury PR. Peri-implant bone loss around posterior mandible dental implants placed after distraction osteogenesis: preliminary findings. $\mathrm{J}$ Periodontol. 2007;78:204-8.

39. Lazar FC, Klesper B, Carls P, Siessegger M, Hidding J, Zoeller J. Callusmassage. A new treatment modality for non-unions of the irradiated mandible. Int J Oral Maxillofac Surg. 2005;34:202-7. 40. Mofid MM, Manson PN, Robertson BC, Tufaro AP, Elias JJ, Vander Kolk CA. Craniofacial distraction osteogenesis: a review of 3278 cases. Plast Reconstr Surg. 2001;108:1103-14.

\section{Conflicts of Interest}

The authors report no conflicts of interest. 